\title{
PERAN NILAI UTILITARIAN DAN HEDONIS TERHADAP KEPUASAN DAN LOYALITAS KONSUMEN MINUMAN PROBIOTIK
}

\author{
Imam Santoso*)1 \\ *) Jurusan Teknologi Industri Pertanian, Fakultas Teknologi Pertania, Universitas Brawijaya \\ Jl. Veteran Malang 65145
}

\begin{abstract}
The rising standard of living and welfare of the community influences the food consuming pattern. This is signified by an increase in demand for probiotics as a functional beverage. This study aims to analyze the role of utilitarian and hedonic attitudes towards customer satisfaction and loyalty. Non-probability and purposive sampling were utilized as the sampling techniques of this study. There were 100 respondents in total participated in the study. The criteria of respondents were ages of 18 and older and consumers of brand $X$ of probiotics beverage for at least twice a month. The data were processed by using the Partial Least Square (PLS). The results showed that the utilitarian value has a significant effect on satisfaction and customer loyalty, while the hedonic one affects customer satisfaction and loyalty. The results of this research also showed that satisfaction has an influence on customer loyalty.
\end{abstract}

Keywords: hedonic, satisfaction, loyalty, probiotics, utilitarian, PLS

\begin{abstract}
ABSTRAK
Meningkatnya taraf hidup dan kesejahteraan masyarakat berpengaruh terhadap pola konsumen pangan. Hal ini ditandai dengan meningkatnya permintaan minuman probiotik sebagai minuman fungsional. Penelitian ini bertujuan menganalisis peran utilitarian dan sikap hedonis terhadap kepuasan dan loyalitas konsumen. Metode pengambilan sampel dalam penelitian ini adalah non probability sampling dengan teknik purposive sampling. Jumlah responden sebanyak 100 orang. Kriteria responden adalah penduduk dengan usia 18 tahun ke atas dan mengkonsumsi minuman probiotik merk X minimal dua kali dalam sebulan. Data diolah menggunakan Partial Least Square (PLS). Hasil penelitian menunjukkan utilitarian berpengaruh signifikan terhadap kepuasan maupun terhadap loyalitas konsumen. Nilai hedonis berpengaruh terhadap kepuasan konsumen dan juga berpengaruh terhadap loyalitas. Hasil riset ini juga menunjukkan bahwa kepuasan berpengaruh terhadap loyalitas konsumen.
\end{abstract}

Kata kunci: hedonis, kepuasan, loyalitas, probiotik, utilitarian, PLS

\footnotetext{
${ }^{1}$ Alamat Korespondensi:

Email: imam.santoso.ub@gmail.com
}

\section{PENDAHULUAN}

Kesadaran masyarakat terhadap kesehatan makin meningkat seiring dengan peningkatan tingkat pendidikan dan kesejahteraan. Hal ini ditandai dengan makin populernya pola hidup sehat. Implikasi dari hal ini adalah terjadinya perubahan pola makan yang mengarah kepada pola konsumsi pangan sehat. Muzayanah et al. (2015) mengungkapkan terdapat kecenderungan peningkatan konsumsi pangan organik. Selain pangan organik, saat ini juga terdapat peningkatan konsumsi pangan fungsional.
Salah satu produk pangan fungsional yang banyak diminati ialah minuman probiotik. Hal tersebut ditandai dengan munculnya beragam produk minuman probiotik dengan berbagai merek yang terdapat di pasaran. Bahkan, promosi di berbagai media mengenai minuman probiotik pun semakin gencar dengan disertai klaim manfaat fungsional bagi kesehatan.

Sejumlah penelitian terkait manfaat minuman probiotik sebagai pangan fungsional telah banyak dilakukan. Salminen dan Ouwehand (2004) menyatakan probiotik sebagai sediaan sel mikroba hidup yang memiliki 
pengaruh menguntungkan terhadap kesehatan dan kehidupan inangnya. Hasil studi Nirmagustina (2007) mengungkapkan, penggunaan minuman fungsional dapat mengurangi kadar total kolesterol serum tikus. Minuman ini dibuat dari tepung kedelai kaya isoflavon dan kaya serat pangan larut. Selain itu, pemberian minuman fungsional ini secara signifikan mengurangi High Density Lipoprotein (HDL), Low Density Lipoprotein (LDL), dan trigliserida. Penelitian lainnya, studi penggunaan ekstrak air cincau hitam yang dilakukan Widyaningsih et al. (2012) menyajikan adanya peluang untuk mencegah terjadinya karsinogenesis pada mencit.

Dari berbagai studi yang menyajikan sejumlah manfaat yang dapat diperoleh dari mengkonsumsi minuman probiotik, telah menarik minat sejumlah produsen untuk berproduksi. Berbagai macam pilihan produk probiotik ditawarkan oleh sejumlah produsen. Konsumen memiliki kesempatan untuk memilih dan mengkonsumsi di antara berbagai pilihan merek. Bahkan konsumen dapat mengganti pilihan produk yang selama ini dikonsumsinya. Salah satu faktor penyebab konsumen yang beralih merek ialah manfaat. Semakin banyak manfaat yang dimiliki produk, maka konsumen lebih tertarik untuk membeli produk tersebut sehingga meninggalkan produk yang lama.

Studi mengenai faktor-faktor yang memengaruhi keputusan pembelian dan kepuasan pelanggan telah banyak dilakukan. Berbagai faktor yang memengaruhi kepuasan pelanggan yang telah dikaji antara lain: kualitas layanan (Aryani dan Rosinta, 2010), atribut produk (Heviandri et al. 2009; Aprianti et al. 2015), loyalitas merek (Kuikka dan Laukkanen, 2012), emosi dan persepsi konsumen Labbe et al. (2015) serta utilitarian dan hedonis (Jones et al. 2006; Cramer dan Antonide, 2011; Nejati dan Moghaddam, 2013; Anderson et al. 2014).

Terdapat sejumlah manfaat yang dapat diperoleh dari membeli atau mengkonsumsi suatu produk. Manfaatmanfaat tersebut berdampak terhadap kepuasan pelanggan. Ailawadi et al. (2001) mengungkapkan manfaat-manfaat yang diterima meliputi utilitarian produk (saving, quality, convenience) dan manfaat hedonis produk (entertainment, exploration, value expresion).
Hasil penelitian Ramadhani (2007) mengungkapkan, seseorang cenderung mengkonsumsi minuman probiotik untuk manfaat utama sebagai minuman yang menunjang kesehatan. Alasan atau motivasi utama karena kandungan probiotiknya yang baik untuk kesehatan. Lahteenmaki dan Ledeboer (2006) menyatakan bahwa beberapa produk probiotik dipasarkan dengan klaim mengenai manfaat terhadap kesehatan pencernaan.

Selain utilitarian produk, konsumen juga menikmati nilai hedonik saat membeli dan mengkonsumsi produk, pengalaman membeli dan mengkonsumsi produk sangat erat berkaitan dengan perasaan, fantasi, kesenangan panca indera yang memengaruhi emosi seseorang. Hasil penelitian Nejati dan Moghaddam (2013) mengungkapkan, nilai-nilai hedonis dan utilitarian memengaruhi signifikan terhadap kepuasan dan keinginan untuk membeli. Selain itu, variabel kepuasan juga dinilai berpengaruh positif signifikan terhadap keinginan membeli. Temuan lain dari penelitian ini adalah nilai utilitarian memiliki pengaruh yang lebih kuat pada keinginan membeli dari pelanggan pada studi kasus restoran cepat saji.

Kota Malang sebagai kota terbesar kedua di Jawa Timur, memiliki potensi ekonomi yang relatif tinggi. Hal ini berdampak terhadap meningkatnya taraf hidup dan kesadaran terhadap pentingnya kesehatan. Meningkatnya kesadaran terhadap kesehatan dan gaya hidup ini telah merubah pola konsumsi termasuk terhadap minuman probiotik. Karena itu dibutuhkan informasiyangmemadaimengenaiperansejumlahfaktor terhadap kepuasan dan loyalitas konsumen minuman probiotik. Tujuan penelitian adalah menganalisis peran nilai utilitarian dan hedonis terhadap kepuasan dan loyalitas konsumen minuman probiotik.

\section{METODE PENELITIAN}

Penelitian ini dilaksanakan di Kota Malang, pada bulan November-Desember 2015. Kota Malang dipilih sebagai lokasi penelitian, karena sebagai salah satu kota besar yang diharapkan masyarakatnya dapat memberikan penilaian persepsional terhadap kepuasan dan loyalitas konsumen terhadap minuman probiotik. Metode pengambilan sampel dalam penelitian ini adalah non probability sampling dengan teknik purposive sampling. Jumlah responden sebanyak 100 orang. Kriteria renponden adalah penduduk dengan 
usia 18 tahun ke atas dan mengkonsumsi minuman probiotik merk X minimal dua kali dalam sebulan. Pengambilan data dilakukan dengan teknik wawancara penyebaran kuesioner kepada responden yang memenuhi kriteria. Kuesioner yang digunakan dalam penelitian ini merupakan kuesioner skala likert dengan rentang penilaian $1-5$. Variabel dan indikator penelitian dapat dilihat pada Tabel 1, sedangkan model struktural variabel penelitian ini dapat dilihat pada Gambar 1.

Dhar dan Wertenbroch (2000) mengungkapkan, utilitarian sebagai salah pertimbangan utama yang bersifat obyektif dan berorientasi pada fungsi atribut produk atau kemanfaatannya. Ailawadi et al. (2001) menyatakan manfaat utilitarian meliputi saving, quality, dan convenience benefits. Sejumlah manfaat ini membantu konsumen memperoleh kegunaan (utility) yang optimal dari produk yang dibelinya. Hasil analisis Cramer dan Antonide (2011) menyajikan perubahan perilaku konsumen yang cenderung berkembang ke nilai utilitarian suatu produk. Namun demikian, kepuasan pelanggan adalah faktor utama yang berperan dalam memengaruhi intensitas pembelian dan tingkat loyalitas. Nejati dan Moghaddam (2013) mengungkapkan, kepuasan konsumen sebagai respon konsumen pada waktu tertentu setelah konsumsi menyukai hasil/ manfaat dari produk. Hasil atau kinerja produk tersebut dirasakan bersesuaian dengan yang diharapkan konsumen.

Loyalitas adalah sikap dan pola perilaku seorang konsumen setelah melakukan pembelian dan penggunaan produk/jasa. Menurut Jones et al. (2006) nilai utilitarian memiliki pengaruh positif dan signifikan terhadap kepuasan pelanggan. Nilai utilitarian memiliki pengaruh terhadap loyalitas seseorang terhadap produk yang dibeli. Muhammad et al. (2013), mengungkapkan, manfaat hedonis adalah adalah manfaat-manfaat yang non-instrumental, memberikan pengalaman, emosi dan perasaan. Nilai hedonik yang tinggi memengaruhi kepuasan konsumen secara emosional. Anderson et al. (2014) menilai pengalaman/nilai hedonik memberi pengaruh bernilai positif terhadap loyalitas konsumen sehingga produsen perlu mempertimbangkan secara cermat dalam tataran implementasinya. Berdasarkan uraian tersebut, rumusan hipotesis, yaitu sebagai berikut:
H1 : Nilai utilitarian berpengaruh positif terhadap kepuasan konsumen
H2 : Nilai utilitarian berpengaruh positif terhadap loyalitas konsumen
H3 : Nilai hedonis berpengaruh positif terhadap kepuasan konsumen

Tabel 1.Variabel dan indikator penelitian

\begin{tabular}{|c|c|c|c|}
\hline Variabel & Notasi & Indikator & Sumber pustaka \\
\hline \multirow{4}{*}{$\begin{array}{l}\text { Nilai } \\
\text { utilitarian } \\
(\mathrm{X} 1)\end{array}$} & $\mathrm{X} 11$ & Manfaat & $\begin{array}{l}\text { Kim dan Han (2011); Hanzaee dan Rezaeyeh } \\
\text { (2013) }\end{array}$ \\
\hline & $\mathrm{X} 12$ & Harga & $\begin{array}{l}\text { Hanzaee dan Khonsari (2011); Hanzaee dan } \\
\text { Rezaeyeh (2013) }\end{array}$ \\
\hline & $\mathrm{X} 13$ & Atribut produk & $\begin{array}{l}\text { Kim dan Han (2011); Hanzaee dan Rezaeyeh } \\
\text { (2013); }\end{array}$ \\
\hline & $\mathrm{X} 14$ & Kualitas produk & $\begin{array}{l}\text { Subagio (2011); Kim dan Han (2011); Çal dan } \\
\text { Adams (2014) }\end{array}$ \\
\hline \multirow{3}{*}{$\begin{array}{l}\text { Nilai hedonis } \\
(\mathrm{X} 2)\end{array}$} & $\mathrm{X} 21$ & Desain kemasan & Schifferstein et al.(2013) \\
\hline & $\mathrm{X} 22$ & Iklan promosi & Kazakeviciute dan Banyte (2012) \\
\hline & $\mathrm{X} 23$ & Kebiasaan mengkonsumsi & Kazakeviciute dan Banyte (2012) \\
\hline \multirow{2}{*}{$\begin{array}{l}\text { Kepuasan } \\
\text { konsumen } \\
\text { (Y1) }\end{array}$} & Y11 & $\begin{array}{l}\text { Puas terhadap kesesuaian manfaat } \\
\text { produk dengan harapan }\end{array}$ & $\begin{array}{l}\text { Aryani dan Rosinta (2010), Hanzaee dan Khonsari } \\
\text { (2011; Angelova dan Zekiri (2011) }\end{array}$ \\
\hline & Y12 & $\begin{array}{l}\text { Puas terhadap kesesuaian manfaat } \\
\text { dengan harga produk }\end{array}$ & Angelova dan Zekiri (2011) \\
\hline \multirow{2}{*}{$\begin{array}{l}\text { Loyalitas } \\
\text { konsumen } \\
\text { (Y2) }\end{array}$} & Y21 & Merekomendasikan kepada orang lain & $\begin{array}{l}\text { Hanzaee dan Rezaeyeh (2013); Anderson et al. } \\
\text { (2014) }\end{array}$ \\
\hline & Y22 & $\begin{array}{l}\text { Tidak memiliki keinginan untuk } \\
\text { berpindah ke produk lain }\end{array}$ & Aryani dan Rosinta (2010) \\
\hline
\end{tabular}




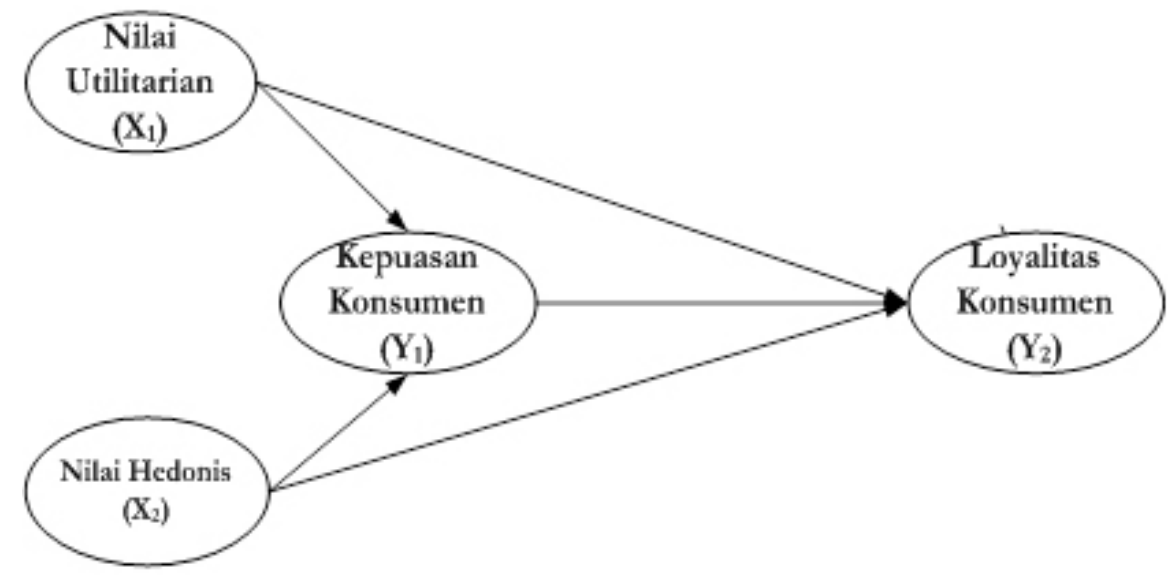

Gambar 1. Model struktural variabel penelitian

H4 : Nilai hedonis berpengaruh positif terhadap loyalitas konsumen

H5 : Kepuasan konsumen berpengaruh positif terhadap loyalitas konsumen

Validitas dan reliabilitas kuesioner dianalisis menggunakan uji instrumen penelitian menggunakan SPSS Statistic 17.0. Pengaruh dan hubungan antar variabel penelitian dianalisis menggunakan alat analisis PLS (Partial Least Square). Diagram jalur konstruk penelitian dapat dilihat pada Gambar 2.

\section{HASIL}

\section{Karakteristik Responden}

Sebagian besar responden berjenis kelamin perempuan (67\%) dan laki-laki sebanyak 33\%. Responden umumnya berusia $17-25$ tahun (89\%) dan usia 26-40 tahun sebanyak $11 \%$. Pendidikan responden sebagian besar SLTA (47\%), SMP/sederajat sebanyak 34\% dan pendidikan sarjana/pascasarjana sebanyak 19\%. Pendapatan responden per bulan sebagian besar (80\%) kurang dari Rp2 juta.

\section{Pendugaan Model Pengukuran dan Struktural}

Diagram jalur menunjukkan diagram hubungan antar variabale nilai utilairian nilai hedonis dan kepuasan konsumen terhadap loyalitas konsumen. Diagram jalur juga menunjukan hubungan antara variabel laten eksogen dan laten endogen. Gambar diagram jalur penelitian dapat dilihat pada Gambar 3.
Seluruh indikator pada kuesioner yang digunakan dalam penelitian telah sesuai dan memenuhi syarat $r$ hitung $>r$ tabel. Semua variabel yang digunakan memiliki Cronbach's alpha yang baik yakni lebih dari 0,6 . Dengan demikian dapat dikatakan bahwa semua instrumen penelitian yang digunakan telah valid dan reliabel.

Hasil analisis menunjukan bahwa semua instrumen pengukuran baik. Nilai AVE dari semua variabel lebih dari 0,5. Hal ini dapat disimpulkan bahwa semua variabel pada penelitian ini valid. Jika dilihat dari konstruk penelitian menunjukan bahwa semua indikator memiliki diskriminan yang cukup, karena nilai setiap indikator lebih besar dibandingkan dengan nilai indikator lainnya. Konstruk bersifat reliabel karena hasil analisis cronbach's alpha dan Composite Reliability seluruh variabel memiliki nilai $>0,6$.

Model struktural dalam PLS dievaluasi dengan menggunakan $\mathrm{R}^{2}$. Nilai $\mathrm{R}^{2}$ digunakan untuk mengetahui tingkat variasi perubahan variabel independen terhadap variabel dependen. Pembentukan model kepuasan konsumen dipengaruhi oleh faktor utilitarian dan hedonis sebesar $45,5 \%$ dan variabel loyalitas dipengaruhi oleh variabel utilitarian dan hedonis dan loyalitas konsumen sebesar 45,4\%. Dengan demikian dapat ditentukan nilai dari $\mathrm{Q}_{2}$ predictive relevance sebagai berikut: $\mathrm{Q}_{2}=1-(1-0,455)-(1-0,454)=1,636$. Nilai dari $\mathrm{Q}_{2}$ pada penelitian ini telah memenuhi syarat konstruk yang memiliki relevansi prediksi yang layak dan dapat digunakan karena nilai dari $\mathrm{Q}_{2}>0$. 


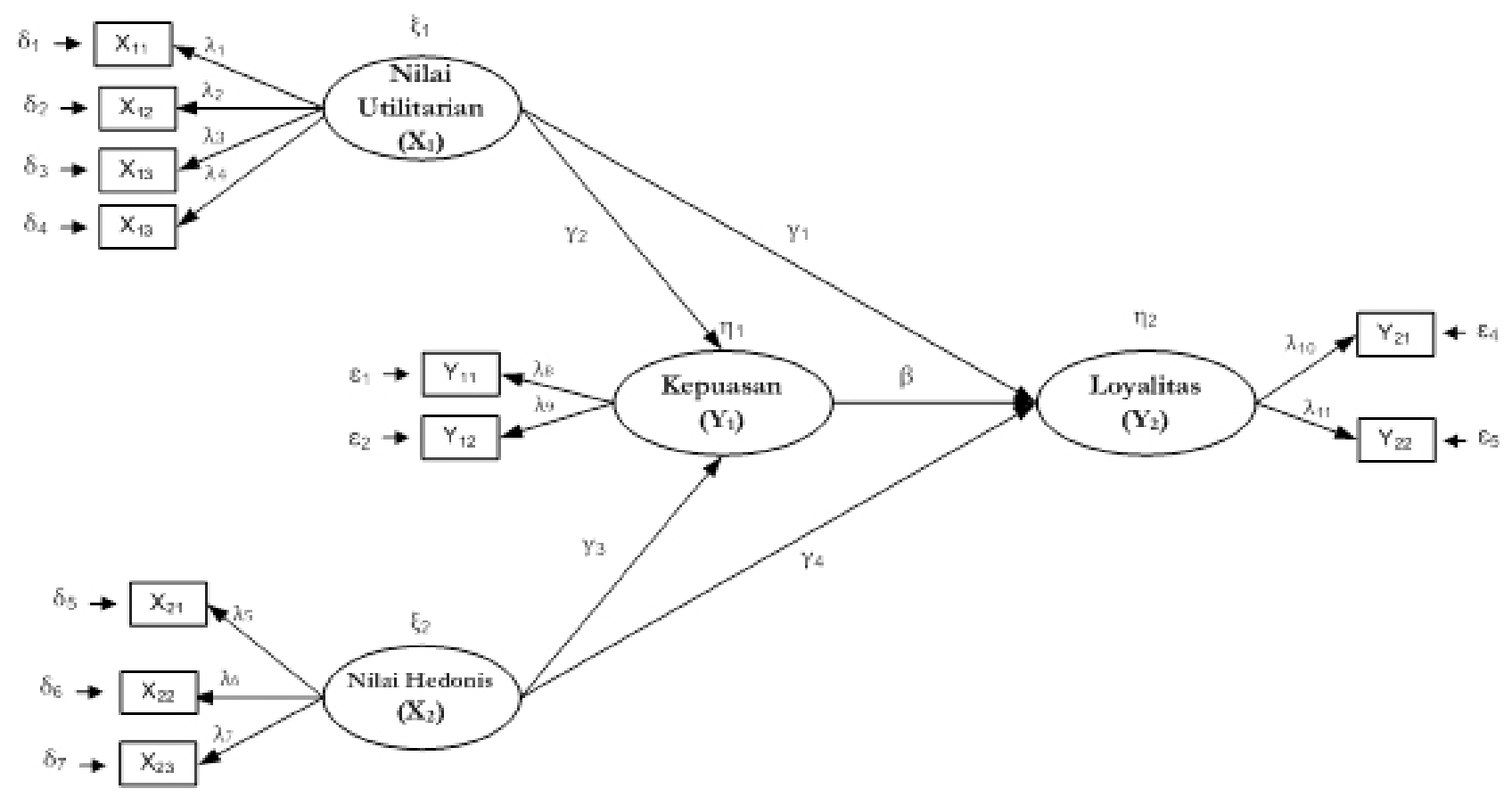

Keterangan:

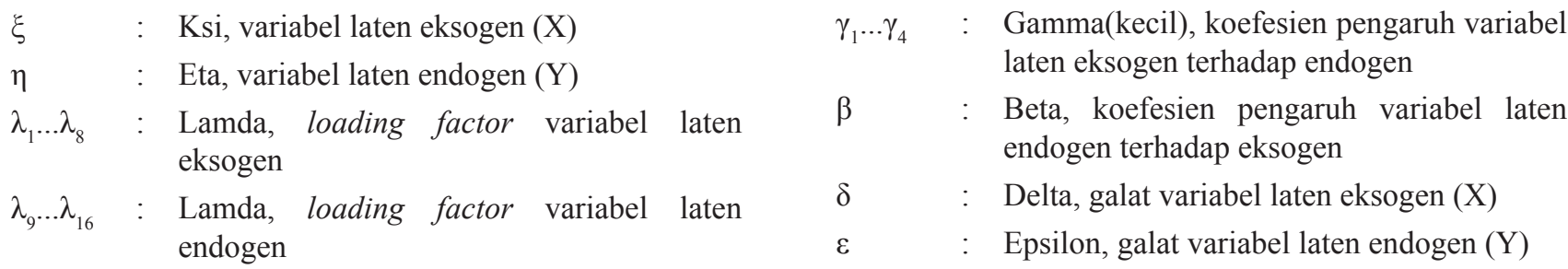

Gambar 2. Diagram jalur konstruk penelitian

Pengujian hipotesis dilakukan dengan metode resampling bootstrap. Pengujian hipotesis dilakukan dengan melihat t-hitung, apabila nilai dari t-hitung $>1,66$ pada tingkat signifikan 5\% maka disimpulkan bahwa hipotesis tersebut signifikan. Hasil pengujian hipotesis didasarkan hasil output PLS. Pengujian hipotesis diperoleh dengan menggunakan perbandingan t-tabel dan t-Statistic. Hasil uji hipotesis dapat dilihat pada Tabel 2.

\section{Peran Nilai Utilitarian}

Hasil uji hipotesis menunjukkan bahwa utilitarian berperan signifikan pada kepuasan konsumen. Nilai utilitarian yang menyebabkan konsumen merasa puas jika mengkonsumsi minuman probiotik $\mathrm{X}$ karena kepercayaan konsumen terhadap minuman probiotik dapat meningkatkan kesehatan, pertimbangan harga yang sesuai dengan manfaaat yang diperoleh, faktor rasa yang menyegarkan dan faktor kualitas produk. Kepuasan konsumen dalam mengkonsumsi minuman probiotik X, ditunjukkan oleh persepsi terhadap manfaat kesehatan yang diperoleh telah sesuai dengan harapan yang diinginkan dan faktor harga produk sesuai dengan manfaat yang diberikan produk.

Hasil analisis ini sejalan dengan sejumlah temuan riset di bidang persepsi pemasaran yang dilakukan beberapa peneliti seperti Jones et al. (2006); Nejati dan Moghaddam (2013); Kuikka dan Laukkanen (2012). Hasil-hasil penelitian tersebut mengemukakan bahwa kepuasan konsumen dipengaruhi oleh beberapa sifat konsumen yaitu hedonis dan utilitarian. Menurut Maehle et al. (2015) aspek penting utilitarian adalah harga dan rasa dari produk pangan. Namun demikian, kelompok konsumen yang memiliki kesadaran tinggi terhadap kesehatan, menempatkan atribut yang bernilai fungsional bagi kesehatan yang paling diperhatikan.

Pengujian hipotesis menunjukkan bahwa utilitarian berpengaruh signifikan pada loyalitas konsumen. Hasil ini sejalan dengan temuan Nejati dan Moghaddam (2013); Anderson (2014) bahwa nilai utilitarian berpengaruh loyalitas. Semakin tinggi keyakinan konsumen terhadap terhadap manfaat produk, kesesuaian harga, atribut minuman probiotik seperti 
rasa dan kualitas produk lainnya akan meningkatkan loyalitas konsumen. Loyalitas ini ditunjukkan dengan merekomendasikan produk kepada orang lain dan tidak berkeinginan pindah ke produk lainnya. Hal ini juga sejalan dengan hasil penelitian Subagio (2011) bahwa motif utilitarian seorang konsumen memengaruhi loyalitasnya. Motif utilitarian seorang konsumen sangat dipengaruhi pada kualitas dan nilai guna suatu produk.

\section{Pengaruh Nilai Hedonis}

Pengujian hipotesis menunjukkan bahwa hedonis berpengaruh signifikan pada kepuasan konsumen. Hal ini berarti usaha-usaha yang dilakukan pihak produsen seperti merancang desain kemasan dan adanya iklan promosi dapat memengaruhi kepuasan konsumen. Selain itu, aspek internal konsumen berupa kebiasaan mengkonsumsi minuman probiotik juga memengaruhi kepuasan konsumen. Dengan demikian, semakin tinggi nilai hedonis produk maka semakin tinggi kepuasan konsumen terhadap produk.
Hasil ini sejalan dengan penelitian yang dilakukan oleh Labbe et al. (2015) bahwa, nilai hedonic (hedonic motivation) mampu memengaruhi kepuasan konsumen. Menurut Schifferstein et al. (2013), kesukaan mengonsumsi suatu produk termasuk dalam motivasi hedonis. Penelitian pada studi kasus di sebuah Restoran di Amerika yang dilakukan Laddhari et al. (2008) mengungkapkan, pemilik restoran menciptakan design restoran yang nyaman dan menyenangkan memengaruhi motivasi hedonis pembeli. Hal ini secara langsung dapat menciptakan kepuasan pembeli. Menurut Kim dan Moon (2009), motivasi hedonis yang diciptakan oleh emosi seseorang karena atmosfer suatu layanan/ produk sangat memengaruhi kepuasan dan loyalitas konsumen. Pada penelitian yang dilakukan Kuikka dan Laukkanen (2012), konsumen yang memiliki sikap hedonis cenderung memiliki tingkat kepuasan yang lebih tinggi dibandingkan konsumen yang memiliki sikap hedonis rendah.

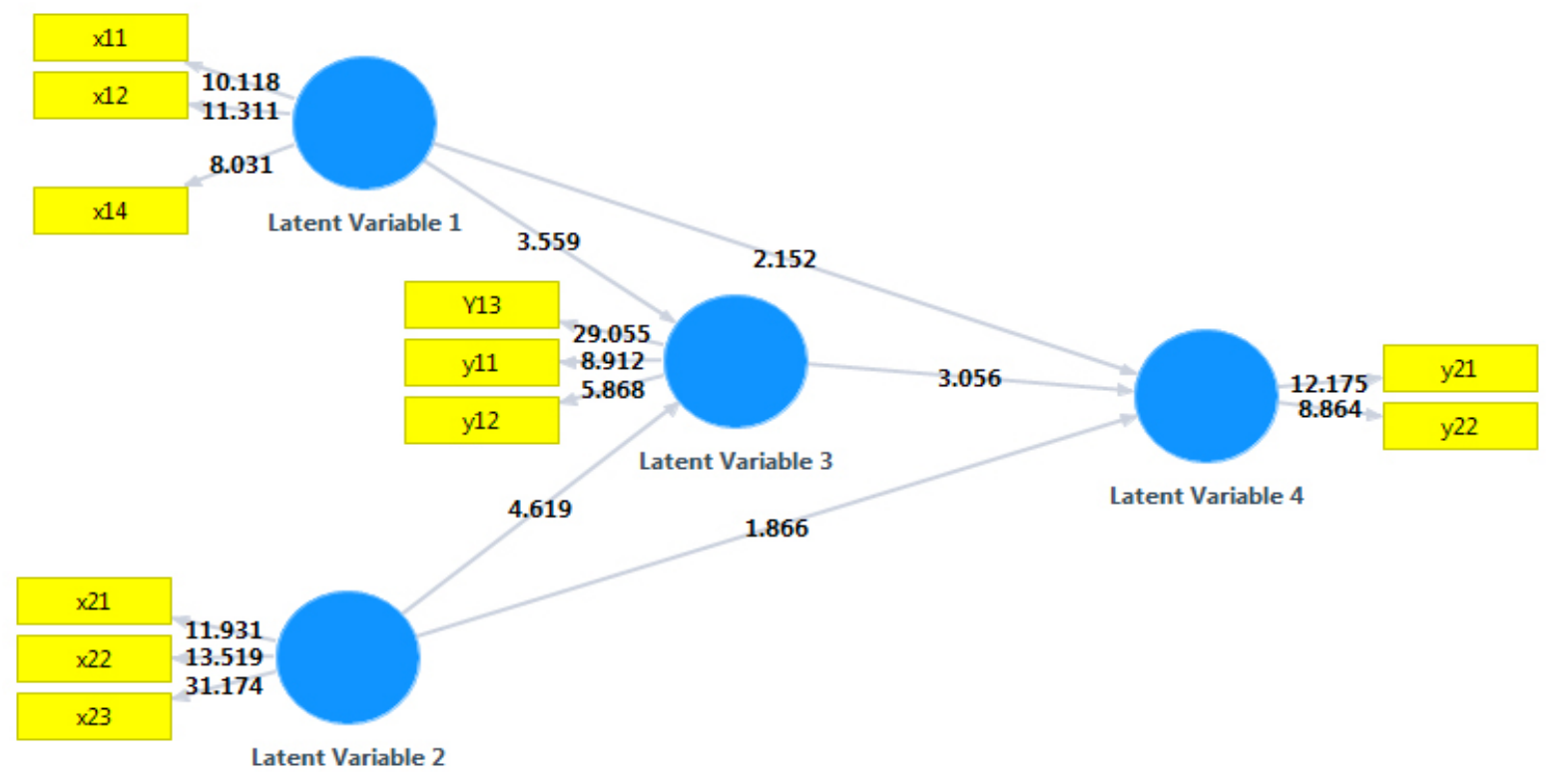

Gambar 3. Diagram jalur penelitian

Tabel 2. Hasil uji hipotesis

\begin{tabular}{lcccc}
\hline \multicolumn{1}{c}{ Hipotesis Statik } & Outer Loading & t-hitung & t-tabel & Ket. \\
\hline Utilitarian - Kepuasan Konsumen & 0,339 & 3,559 & 1,66 & Signifikan \\
Utilitarian - Loyalitas & 0,238 & 2,152 & 1,66 & Signifikan \\
Hedonis - kepuasan & 0,430 & 4,619 & 1,66 & Signifikan \\
Hedonis - loyalitas & 0,193 & 1,866 & 1,66 & Signifikan \\
Loyalitas konsumen - Kepuasan & 0,359 & 3,056 & 1,66 & Signifikan \\
\hline
\end{tabular}


Nilai hedonis para konsumen minuman probiotik berpengaruh secara signifikan terhadap loyalitas konsumen. Hasil analisis ini sejalan dengan sejumlah penelitian terdahulu, seperti yang dilakukan oleh Kim dan Moon, (2009); Subagio (2011); Kuikka dan Laukkanen (2012) yang menyatakan bahwa hedonik berpengaruh positif signifikan terhadap loyalitas konsumen. Motivasi hedonis yang diciptakan oleh emosi seseorang baik karena faktor internal dan eksternal sangat memengaruhi loyalitas konsumen.

Di sisi lain, hasil penelitian ini tidak sejalan dengan hasil penelitian Hu dan Chuang (2012) bahwa nilai hedonis tidak berpengaruh nyata terhadap loyalitas. Diungkapkan, lemahnya pengaruh langsung hedonis terhadap loyalitas diduga karena nilai hedonis membutuhkan variabel antara seperti kepuasan konsumen dalam memengaruhi loyalitas konsumen.

\section{Dampak Kepuasan Konsumen terhadap Loyalitas Konsumen}

Hasil penelitian ini, kepuasan berpengaruh positif terhadap loyalitas konsumen. Semakin tinggi tingkat kepuasan konsumen terhadap manfaat yang telah diperoleh dari suatu produk, maka ia akan loyal terhadap produk tersebut. Kepuasan ini direfleksikan oleh dua indikator manfaat dan kesesuaian biaya. Tingkat kemanfaatan suatu produk yang dirasakan konsumen akan mengakibatkan konsumen tidak berpindah ke produk lain dan bahkan merekomendasikan produk probiotik merek X ke orang lain.

Hasil ini sejalan dengan penelitian yang dilakukan oleh Dick dan Basu (2005), ketika seorang konsumen memiliki persepsi manfaat yang tinggi maka hal ini menunjukkan bahwa tingkat kepuasan terhadap produk tersebut sangat tinggi. Dengan kepuasan yang tinggi maka konsumen akan tidak berganti ke merek yang lain. Hasil penelitian Kuikka dan Laukkanen (2012) memperkuat temuan penelitian ini, kepuasan konsumen merupakan faktor yang paling berpengaruh terhadap loyalitas konsumen. Selanjutnya, diikuti dengan faktor manfaat, ekuitas dan faktor kepercayaan memiliki tingkat signifikan yang terkecil terhadap loyalitas konsumen. Hasil penelitian ini menguatkan pendapat bahwa loyalitas merupakan wujud komitmen mendalam dari konsumen untuk setia tidak berpindah ke produk lainnya, walaupun di saat yang bersamaan terdapat sejumlah pengaruh yang bersifat situasional dan berbagai usaha pemasaran yang dapat memengaruhi atau bahkan mengakibatkan perubahan perilaku. Bahkan, loyalitas konsumen ditunjukkan dengan merekomendasikan produk tersebut ke orang lain.

\section{Implikasi Manajerial}

Membangun loyalitas tidak dapat dipisahkan dari usaha untuk meraih dan meningkatkan kepuasan pelanggan. Hasil penelitian ini memperkuat bahwa nilai utilitarian dan hedonis berpengaruh terhadap kepuasan pelanggan dan bahkan nilai utilitarian juga berpengaruh secara langsung terhadap loyalitas pelanggan. Pengembangan minuman probiotik sebagai salah satu produk fungsional yang bermanfaat untuk kesehatan membutuhkan usahausaha untuk meningkatkan nilai utilitarian produk. Hal ini karena nilai utilitarian sebagai salah satu kekuatan utama menawarkan produk kepada konsumen supaya berhasil dengan baik. Selain itu, aspek desain kemasan dan iklan promosi harus dapat mengemas nilai utilitarian secara baik agar dapat menumbuhkan sikap hidonis terhadap produk fungsional.

\section{KESIMPULAN DAN SARAN}

\section{Kesimpulan}

Utilitarian berpengaruh signifikan terhadap kepuasan maupun terhadap loyalitas konsumen. Hal ini memberikan makna bahwa nilai utilitarian selain berdampak terhadap tingkatkepuasan, juga berpengaruh terhadap loyalitas. Dengan demikian, sangat penting mempertimbangkan nilai utilitarian produk minuman probiotik bagi konsumen. Demikian juga, nilai hedonis berpengaruh signifikan terhadap kepuasan konsumen dan berpengaruh terhadap loyalitas. Upaya memengaruhi nilai hedonis yang dilakukan melalui iklan promosi dan desain kemasan perlu lebih difokuskan untuk meningkatkan kepuasan pelanggan dan loyalitas. Selain itu, kepuasan berpengaruh terhadap loyalitas konsumen. Hal ini memberikan makna bahwa untuk membangun loyalitas perlu didorong melalui upaya-upaya komprehensif dalam rangka meningkatkan kepuasan konsumen.

\section{Saran}

Hasil penelitian, produsen dalam melakukan riset dan pengembangan produk perlu mempertimbangkan nilai utilitarian dan faktor hedonis konsumen. Selain itu, strategi pemasaran yang dikembangkan 
perlu menonjolkan nilai utilitarian dengan tetap memperhatikan aspek selera, citarasa, kenyamanan dan kepraktisan dalam mengkonsumsi. Penelitian lanjutan dapat dilakukan dengan mempertimbangkan berbagai variabel lainnya seperti harga, ukuran kemasan, dan rasa minuman, lokasi penjualan, dan sebagainya.

\section{DAFTAR PUSTAKA}

Ailawadi KL, Lehmann DR, Neslin SA. 2001. Market response to a major policy change in the marketing mix: learning from procter \& gamble's value pricing strategy. Journal Marketing 65(1):4461.

Anderson KC, Knight DK, Pookulangara S, Josiam B. 2014. Influence of hedonic and utilitarian motivations on retailer loyalty and purchase intention: a facebook perspective. Journal Retailing and Consumer Service 21:773-779.

Aprianti A, Suharjo B, Muflikhati I.2015. Positioning pupuk hayati (Studi kasus PT. Karya Anugrah Rumpin), Jurnal Manajemen \& Agribisnis 12 (2):106-114.

Aryani D, Rosinta F. 2010. Pengaruh Kualitas Layanan terhadap Kepuasan Pelanggan dalam Membentuk Loyalitas Pelanggan. Bisnis \& Birokrasi, Jurnal Ilmu Administrasi dan Organisasi 17(2):114126.

Çal B, Adams R. 2014. The effect of hedonistic and utilitarian consumer behavior on brand equity: Turkey-UK Conparison on Coca Cola. Social and Behavioral Sciences 150:475-484.

Cramer L, Antonide G. 2011. Endowment effects for hedonic and utilitarian food products. Journal Food Quality and Preference 22:3-10.

Dhar R, Wertenbroch K. 2000. Consumer choice between hedonic and utilitarian goods. Journal Marketing Research 37:60-71.

Dick AS, Basu K. 2005. Customer loyalty: toward an integrated conceptual framework. Journal Academy of Marketing Science 22(2):99-113.

Jones MA, Reynolds KE, Arnold MJ. 2006. Hedonic and utilitarian shopping value: Investigating differential effects on retail outcomes. Journal Business Research 59(9):974-981.

Hamzaee KH, Khonsari Y. 2011. A review of the role of hedonic and utilitarian values on customer's satisfaction and behavioral intentions. Interdisciplinary Journal of Research in Business 1(5):34-45.
Hanzaee KH, Rezaeyeh SP. 2013. Investigation of the effects of hedonic value and utilitarian value on Customer satisfaction and behavioural intentions. African Journal of Business Management 7(11):818-825.

Heviandri R, Sumarwan U, Retnaningsih. 2009. Analisis kepuasan konsumen terhadap layanan di Bandara Soekarno-Hatta serta implikasinya terhadap strategi pemasaran City Check-in terminal di Jakarta. Jurnal Manajemen \& Agribisnis 6(2):124-139.

Kazakeviciute A, Banyte J. 2012. The Relationship of consumers perceived hedonic value and behavior Inzinerine Ekonomika-Engineering Economics 23(5):532-540.

Kim B, Han I. 2011. The role of utilitarian and hedonis values and their antecendents in mobile data service environment. Expert Systems with Applications 38:2311-2318.

Kim WG, Moon YJ. 2009. Customers' cognitive, emotional, and actionable response to the servicescape: A test of the moderating effect of the restaurant type. Journal Hospitality Management 28:144-156.

Kuikka A, Laukkanen T. 2012. Brand loyalty and the role of hedonic value. Journal Product \&Brand Management 21:529-537.

Labbe D, Ferrage A, Rytz A, Pace J, Martin N. 2015. Pleasantness, emotions and perceptions induced by coffee beverage experience depend on the consumption motivation (hedonic or utilitarian). Journal Food Quality and Preference 44:56-61.

Lahteenmaki L, Ledeboer AM. 2006. Probiotics: The Consumer perspective. Food Science and Technology. Bulletin Functional Foods 3(5):4750.

Maehle N, Iversen N, Hem L, Otnes C. 2015. Exploring consumer preferences for hedonic and utilitarian food attributes. British Food Journal 117 (12):3039-3063.

Muhammad NS, Musa R, Ali SN. 2013. Unleashing the effect of store atmospherics on hedonic experience and store loyalty. Journal Social and Behavioral Sciences 130: 469-478.

Muzayanah FN, Suroso AI, Najib M. 2015. FaktorFaktor yang memengaruhi resistensi pembelian pangan organik dan proses pendidikan konsumen. Jurnal Manajemen \& Agribisnis 12(3):163173.

Nejati M, Moghaddam PP. 2013. The effect of hedonic and utilitarian values on satisfaction and 
behavioural intentions for dining in fast-casual restaurants in Iran. British Food Journal 115(11): 1583-1596.

Nirmagustina DE. 2007. Pengaruh minuman fungsional mengandung tepung kedelai kaya isoflavon dan serat pangan larut terhadap kadar total kolesterol dan trigliserida serum Tikus percobaan. Jurnal Teknologi dan Industri Hasil Pertanian 12(2):47-52.

Ramadhani R. 2007. Analisis perilaku konsumen dalam proses keputusan pembelian minuman kesehatan probiotik Yakult. Bogor: Program Studi Manajemen Agribisnis, Fakultas Pertanian, Institut Pertanian Bogor.

Salminen W, Ouwehand. 2004. Lactic acid bacteria: microbiology and functional aspect. 3th edition. revised and expanded. New York: Marcel Dekker Inc.

Schifferstein HNJ, Fenko A, Desmet PMA, Labbe D, Martin N. 2013. Influence of package design on the dynamics of multisensory and emotional food experience. Journal Food Quality and Preference 27:18-25.

Subagio H. 2011. Pengaruh atribut supermarket terhadap motif belanja hedonik motif belanja utilitarian dan loyalitas konsumen. Jurnal Manajemen Pemasaran 6(1):8-21.

Widyaningsih TD, Sukardiman, Purwanto DA, Darmanto W. 2012. efek imunomodulator ekstrak air cincau hitam (mesona palustris BL) terhadap karsinogenesis mencit. Jurnal Teknologi dan Industri Pangan 13(1) :29-35. 